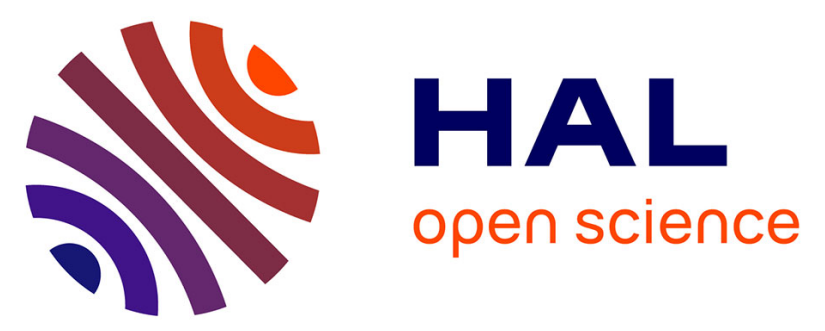

\title{
Residue levels of captan and trichlorfon in field-treated kaki fruits, individual versus composite samples, and after household processing
}

María Luisa Fernández-Cruz, Susana Grimalt, Mercedes Villarroya, Francisco José López, Susana Llanos, José María García-Baudín

\section{To cite this version:}

María Luisa Fernández-Cruz, Susana Grimalt, Mercedes Villarroya, Francisco José López, Susana Llanos, et al.. Residue levels of captan and trichlorfon in field-treated kaki fruits, individual versus composite samples, and after household processing. Food Additives and Contaminants, 2006, 23 (06), pp.591-600. 10.1080/02652030500529460 . hal-00577581

\section{HAL Id: hal-00577581 \\ https://hal.science/hal-00577581}

Submitted on 17 Mar 2011

HAL is a multi-disciplinary open access archive for the deposit and dissemination of scientific research documents, whether they are published or not. The documents may come from teaching and research institutions in France or abroad, or from public or private research centers.
L'archive ouverte pluridisciplinaire HAL, est destinée au dépôt et à la diffusion de documents scientifiques de niveau recherche, publiés ou non, émanant des établissements d'enseignement et de recherche français ou étrangers, des laboratoires publics ou privés. 


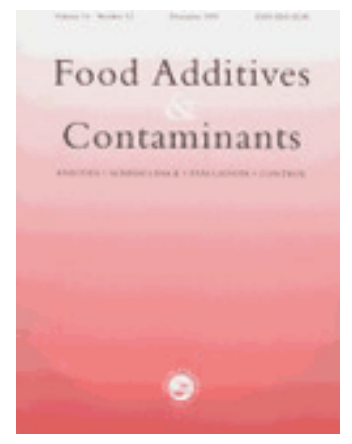

\section{Residue levels of captan and trichlorfon in field-treated kaki fruits, individual versus composite samples, and after household processing}

\begin{tabular}{|c|c|}
\hline Journal: & Food Additives and Contaminants \\
\hline Manuscript ID: & TFAC-2005-326.R1 \\
\hline Manuscript Type: & Original Research Paper \\
\hline $\begin{array}{r}\text { Date Submitted by the } \\
\text { Author: }\end{array}$ & 13-Dec-2005 \\
\hline Complete List of Authors: & $\begin{array}{l}\text { Fernández-Cruz, María Luisa; Instituto Nacional de Investigación y } \\
\text { Tecnología Agraria y Alimentaria (INIA), Protección Vegetal } \\
\text { Grimalt, Susana; Universidad Jaume I, Instituto Universitario de } \\
\text { Plaguicidas y Aguas, Laboratorio de Análisis de Residuos de } \\
\text { Plaguicidas } \\
\text { Villarroya, Mercedes; Instituto Nacional de Investigación y } \\
\text { Tecnología Agraria y Alimentaria (INIA), Protección Vegetal } \\
\text { López, Francisco José; Universidad Jaume I, Instituto Universitario } \\
\text { de Plaguicidas y Aguas, Laboratorio de Análisis de Residuos de } \\
\text { Plaguicidas } \\
\text { Llanos, Susana; Instituto Nacional de Investigación y Tecnología } \\
\text { Agraria y Alimentaria (INIA), Protección Vegetal } \\
\text { García-Baudín, José María; Instituto Nacional de Investigación y } \\
\text { Tecnología Agraria y Alimentaria (INIA), Protección Vegetal }\end{array}$ \\
\hline Methods/Techniques: & Risk assessment, Chromatographic analysis \\
\hline Additives/Contaminants: & Pesticide residues \\
\hline Food Types: & Fruit \\
\hline
\end{tabular}

\section{SCHOLARONE \\ Manuscripts}




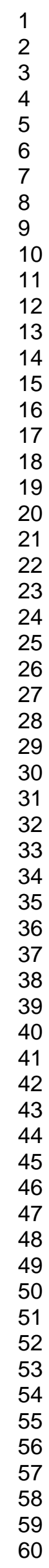 \\ Page 1 of 32}

1

2

4

5

6
7

8

10

11

12

14

15

16

17

18

19

20

22

23

25

26

27

29

30

32

33

34

35

36

(37

39

40

41

42

44

45

46

47

48

50

51

53

54

55

57

58

60

http://mc.manuscriptcentral.com/tfac Email: fac@tandf.co.uk 


\section{Abstract}

2

3 The dissipation of residue levels of captan and trichlorfon in field-treated kaki crops

4 were followed according to Good Laboratory Practice (GLP). Residue levels of captan

5 and trichlorfon were determined by GC/MS and LC-MS/MS enabling maximum residue

6 limits (MRLs) of 3 and $5 \mathrm{mg} / \mathrm{kg}$, respectively to be proposed. The behaviour of these

7 residues was also studied after peeling and cooking and in individual kaki fruits

8 compared with composite samples. Residue levels of these compounds for individual

9 fruits suggested that a variability factor up to 3 could be set for the acute risk

10 assessment. Levels of captan decreased more than $90 \%$ after peeling and completely

11 after cooking. About $70 \%$ of the residue at the pre-harvest interval (PHI) for trichlorfon

12 was found to penetrate into the flesh of the kaki fruit. Cooking resulted in a reduction

13 of $27 \%$ of trichlorfon residue levels.

16 Keywords: residue, captan, folpet, dichlorvos, trichlorfon, metabolites, variability

17 factor, processing, kaki, vegetable and minor crop 


\section{Introduction}

Harmonization of maximum residue limits (MRLs), especially in minor crops, and the risk assessment of these residues for the consumer are currently main objectives in Europe. Kaki (Diospyros kaki L.f.) is an important minor crop in Spain, with the $70 \%$ of the production exported mainly to the European market. Kaki fruits have been found to be excellent source of pro-vitamin A, mainly beta-carotene, with anti-oxidative properties.

Captan (3a,4,7,7a-tetrahydro-2-[(tricloromethyl)thio]-1H-isoindole-1,3(2H)-dione) is a fungicide of the phthalimide group. Captan is registered in Spain for treatment of fruit trees for the control of anthracnose, brown rot and scab. The European residue definition of captan is the sum of captan and folpet. Folpet (2-[(trichloromethyl)thio]$1 H$-isoindole-1,3(2H)-dione) is also a fungicide of the phthalimide group. Trichlorfon (dimethyl 2,2,2-trichloro-1-hydroxyethylphosphonate) is a non-systemic organophosphate insecticide for the control of different categories of insects on many crops. In Spain, trichlorfon is registered in kaki for control of ceratitis and carpocapsa, two important pests for this crop.

Determination of captan/folpet and trichlorfon in fruits has been reported in the literature using mainly gas chromatographic methods (Mattern et al. 1990, Mattern et al. 1991, Niessner et al. 1999, Angioni et al. 2003). The major problem of trichlorfon is its thermal instability, particularly in the injection port. In order to avoid this dehydrohalogenation to dichlorvos (2,2-dichlorovinyl dimethyl phosphate) derivative has been performed for analysis (Conrad et al. 1987). Other authors prevent the 
hydrolysis of trichlorfon to dichlorvos by adding hydrochloric acid (Spieszalski and Niemczyk 1991). On-column injection methods permit the analysis of trichlorfon in agricultural foods without derivatization (Brito et al. 2002).

The study reported here had two different major objectives. The main objective was to study the fate of captan, folpet and of trichlorfon after kaki field application of captan and trichlorfon (as commercial formulations), respectively, in order to establish and propose MRLs and to obtain dissipation curves to predict the pre-harvest interval (PHI). Residue analysis was performed in our Laboratory of Pesticide Residue Analysis (LARP) of the University Jaume I following the Principles of Good Laboratory Practices (GLP), which are mandatory for these kinds of studies. We have developed and validated an analytical method based on gas chromatography-mass spectrometry (GC-MS) in negative chemical ionisation mode for the simultaneous determination of captan and folpet, after extraction with acetone and clean-up by solid phase extraction (Barreda et al. 2005). In the same way, an analytical method based on liquid chromatography-tandem mass spectrometry (LC-MS/MS) in positive ionisation mode by electrospray after extraction with acetonitrile, has also been developed and in-house validated for trichlorfon residue analysis. The validation of the methods (specificity, precision, recovery, and limit of determination) were performed according to European requirements and guidelines (European Communities 1996, European Commission 2000a) at two concentration levels $(0.05$ and $0.5 \mathrm{mg} / \mathrm{kg})$.

Another objective of this study was to establish the behaviour of the residues after the processing of the vegetable products as well as the variability of the residues between 


\section{Materials and methods}

\section{Field trials}

Kaki plots were treated in October 2002 and October-December 2003 according with European guidelines (European Commission 2000b) ("see Table 1"). Four different sites located in the east of Spain (Comunidad Valenciana) were selected. The variety studied for kaki is Rojo Brillante (provided with designation of origin). In each site three plots were chosen as control plot and treated plot. Plots of kaki contained 4 to 11 trees, which were 4 to 12 years old. The planting distance in kaki plots varied from 2 to $5 \mathrm{~m}$ between lines and 1.5 to $5.5 \mathrm{~m}$ between trees. Captan $50 \%$ wettable powder (WP) w/w and trichlorfon $80 \%$ water-soluble powder (SP) w/w were sprayed as recommended with a manual sprayer at $300 \mathrm{~g} / \mathrm{hl}$ of water to each treated plot. A single application was made. An agro meteorological station located near each site collected 
meteorological data. During the whole experiments, the minimum/maximum daily air temperatures and total rainfall were registered (“see Table I”).

"[Insert Table I about here]"

\section{Sample collection and preparation}

Samples were gathered in control and treated plots before application of the product (time 0-), 2-3 hours post-application (time 0+), at intermediate times 2, 3, 5 and 7 days (only in 4 plots for dissipation assays, 2 in each consecutive year) (times 2, 3, 5 and 7) and at PHI, 7 and 10-days post-application for captan and trichlorfon, respectively. At each time, at least 12 or 24 kaki fruits without peduncle weighing about 2 or $4 \mathrm{~kg}$, respectively were collected randomly per plot taking fruits from all parts of at least four trees (top, bottom, inside, outside) as recommended by European guidelines (European Commission 2000b), transported at $4^{\circ} \mathrm{C}$ and darkness in labelled polyethylene bags to the laboratory where fruits of each plot were sub sampled, processed according to the following studies and stored at $-20^{\circ} \mathrm{C}$ until analysis:: (a) 6 fruits per plot 1,3 and 4 were analysed individually as whole raw kakis by GC/ECD, (b) 12 fruits divided in two groups of 6 fruits were peeled with a kitchen knife. The thickness of the peel removed in that way was approximately $2 \mathrm{~mm}$. Composite samples of flesh and peel were analysed separately by GC/ECD and GC/MS or LC-MS/MS or only by GC/MS or LCMS/MS (plots 2, 5, 6, 7 and 8), (c) 6 fruits from plots 1, 3 and 4 were homogenized for residue level study of raw and boiled kaki, $650 \mathrm{~g}$ were cooked without water during 20 minutes when cooking has started. Analysis was conducted by GC/ECD. Weights of individual kaki fruits ranged between 160 and $290 \mathrm{~g}$. 


\section{Analytical procedure}

Reagents. HPLC-grade cyclohexane and ethyl acetate were purchased from Lab-Scan Ltd. (Dublin, Ireland). HPLC-grade water was obtained from a Barnstead Nanopure II System (Iowa, USA). HPLC-grade acetonitrile and methanol, residue analysis grade acetone, trace analysis grade dichloromethane and hexane, pure zinc acetate dihydrate and Supelclean Envi-Chrom $500 \mathrm{mg} / 6 \mathrm{ml}$ solid phase extraction tubes were obtained from ScharLab (Barcelona, Spain). Sodium sulphate anhydrous, granular for analysis, was purchased from Merck (Darmstadt, Germany). Captan (purity, 99.5\%), folpet (purity, $98 \%)$, captan $\mathrm{D}_{6}\left(100 \mu \mathrm{g} / \mathrm{ml}\right.$ in acetone), folpet $\mathrm{D}_{4}(100 \mu \mathrm{g} / \mathrm{ml}$ in acetone), trichlorfon (purity, $97.5 \%$ ) and dichlorvos (purity, 99.0\%) were obtained from Dr. Ehrenstorfer GmbH (Augsburg, Germany). Helium and nitrogen were from Air Liquide España (Madrid, Spain).

Apparatus. An electric crusher K55E (Dito Sama, Aubusson, France), a mixer-extractor Ultraturrax T25 (Janke \& Kunkel, Staufen, Germany), a centrifuge Consul (Orto-Alresa, Ajalvir, Madrid, Spain), a Multibloc bath (J.P. Selecta, Barcelona, Spain), a Sorvall RC5C Plus centrifuge (Heraeus, Madrid, Spain) and a Heidolph rotary evaporator Model Laborota 4000 (Droquima, S.L., Madrid, Spain) were used for sample preparation and extraction procedure. Analyses of captan and folpet under GLP were performed using an Agilent 6890A gas chromatograph (Agilent, Avondale, USA) equipped with an Agilent 5973N mass selective detector in negative chemical ionisation mode (methane as reagent gas) and a CIS4 PTV injector (Gerstel, Aktingstrabe, Mülheim an der Ruhr, Germany). A Waters Alliance 2795 HPLC system coupled to a Quattro Micro mass spectrometer with an orthogonal Z-spray-electro spray interface 
(Waters, Milford, MA, USA) was used for trichlorfon analysis under GLP. Captan, dichlorvos, folpet and trichlorfon were analysed with a Varian CP-3800 gas chromatographs equipped with a Varian electron capture detector and a split-split less injector Model 1079 with a Varian CP-8410 automatic injector (Varian Iberia, S.L., Madrid, Spain).

Captan GC-MS determination. Ten $\mathrm{ml}$ of $0.1 \mathrm{M}$ zinc acetate solution were added to $20 \mathrm{~g}$ of homogenised and triturated kaki flesh, or $10 \mathrm{~g}$ in case of kaki peel, and then were fortified with $1 \mathrm{ml}$ of the mixture $500 \mathrm{ng} / \mathrm{ml}$ acetone of internal standards captan $\mathrm{D}_{6}$ and folpet $\mathrm{D}_{4}$. At ambient temperature, $60 \mathrm{ml}$ of acetone were added and at high speed in a mixer-extractor Ultraturrax the samples were extracted. The homogenate of peel was filtered through pleat paper filters by gravity whereas the homogenate of flesh was centrifuged in a Consul centrifuge at $3000 \mathrm{rpm}$ during $5 \mathrm{~min}$ and filtered in a Büchner funnel with vacuum. Final volume was adjusted to $100 \mathrm{ml}$ with acetone in a volumetric flask. An aliquot of $20 \mathrm{ml}$ was adjusted to $100 \mathrm{ml}$ with HPLC-grade water. This extract was passed through a Envi-Chrom solid phase extraction tube, previously conditioned with $4 \mathrm{ml}$ of acetone and $4 \mathrm{ml}$ of HPLC water, applying a vacuum of $10^{4} \mathrm{~Pa}$ approximately. The tube was dried by nitrogen or air during 1 hour. Then, it was eluted with $8 \mathrm{ml}$ of dichloromethane and this eluted was evaporated to dryness with nitrogen in a Multibloc bath at $40^{\circ} \mathrm{C}$. The residue was dissolved in $1 \mathrm{ml}$ of hexane and $2 \mu \mathrm{l}$ were injected in the Agilent GC/MS system. The GC/MS system was fitted with a $30 \mathrm{~m} \mathrm{x}$ $0.25 \mathrm{~mm}$ I.D., $0.25 \mu \mathrm{m}$ HP-5MS column (J\&W Scientific). Injection conditions were as follows: pulsed split-less injection mode (initial pressure $172.4 \mathrm{KPa}(1.5 \mathrm{~min})$, pressure 60.3 KPa); injection volume, $2.0 \mu \mathrm{l}$; injector temperature program: $40^{\circ} \mathrm{C}$, increase to 
$150^{\circ} \mathrm{C}$ at $10^{\circ} \mathrm{C} / \mathrm{s}$ and hold $0.5 \mathrm{~min}$. The column temperature program used was $1.0 \mathrm{~min}$ at $90^{\circ} \mathrm{C}$, increase to $200^{\circ} \mathrm{C}$ at $30^{\circ} \mathrm{C} / \mathrm{min}$, and finally increase to $250^{\circ} \mathrm{C}$ at $4{ }^{\circ} \mathrm{C} / \mathrm{min}(4.83$ min). The temperature of the transfer line was set at $250{ }^{\circ} \mathrm{C}$. The ions used for quantification were m/z 150 (captan), m/z 156 (captan $\mathrm{D}_{6}$ ), m/z 146 (folpet) and m/z 150 (folpet $\mathrm{D}_{4}$ ). Quantification of captan and folpet is based in the method of the internal standard (relate to captan $\mathrm{D}_{6}$ and folpet $\mathrm{D}_{4}$ ) and calibration curve in blank matrix extract. Individual stock standard solutions were prepared in acetone for captan, folpet, captan $\mathrm{D}_{6}$, and folpet $\mathrm{D}_{4}$, then mixed standard solutions of captan and folpet were prepared ranging from 0.05 to $2.5 \mu \mathrm{g} \mathrm{ml}^{-1}$ in acetone, containing $0.1 \mu \mathrm{g} \mathrm{ml}^{-1}$ of the mixture of the deuterium compounds. The mixed standards were used for the preparation of matrix-matched standard and for the fortification of blank extracts.

Trichlorfon LC-MS/MS determination. The extraction of $20 \mathrm{~g}$ of kaki flesh, or $10 \mathrm{~g}$ in the case of kaki peel, with $60 \mathrm{ml}$ of acetonitrile at high speed in a mixer-extractor Ultraturrax was performed at ambient temperature during $2 \mathrm{~min}$. The homogenate was filtered in a Büchner funnel with vacuum through filter paper. Final volume was adjusted to $100 \mathrm{ml}$ with acetonitrile in a volumetric flask. An aliquot of $2.5 \mathrm{ml}$ of the extract was adjusted to $10 \mathrm{ml}$ with HPLC-grade water, $20 \mu \mathrm{l}$ of this extract dilution was injected in the HPLC-MS/MS system that was fitted with a Discovery $\mathrm{C}_{18} 5 \mu \mathrm{m}, 50 \times 2$ mm column (Supelco, Bellefonte, USA). The mobile phase flow rate was adjusted to $0.3 \mathrm{ml} / \mathrm{min}$ and the gradient elution was $5 \%$ methanol:95\% water from 0 to $7 \mathrm{~min}$, increasing to $50 \%$ methanol at $12 \mathrm{~min}$ and decreasing to $5 \%$ methanol at $13 \mathrm{~min}$. The total run time was $15 \mathrm{~min}$. The mass spectrometer in positive ionisation mode by electrospray (ES+) was optimized for trichlorfon obtaining 257 and $109 \mathrm{~m} / \mathrm{z}$ as 
precursor ion and product ion, respectively. The optima capillary, cone voltage and collision energy was respectively $3.5 \mathrm{kV}, 30 \mathrm{~V}$ and $15 \mathrm{eV}$ for the selected mass transition. The dwell time for each transition was $0.5 \mathrm{~s}$. The desolvation and source temperature were $350^{\circ} \mathrm{C}$ and $120^{\circ} \mathrm{C}$, respectively. Nitrogen was the desolvation gas with a flow of $600 \mathrm{~L} / \mathrm{h}$. Argon C-45 was the collision gas with a pressure setting of $0.3 \mathrm{~Pa}$. Quantification of trichlorfon is based in the method of the external matrix matched standard calibration curve. Individual stock standard solutions were prepared in methanol. The final standard solutions for calibration curves (9 points) ranged from 0.5 to $250 \mathrm{ng} / \mathrm{ml}$.

Captan GC-ECD determination. Whole raw, flesh and cooked kaki (25 g) homogenized in a blender were mixed in a rotary stirrer $(5 \mathrm{~min})$ with 2 portions of $50 \mathrm{ml}$ ethyl acetate and $20 \mathrm{~g}$ of sodium sulphate. For the analysis of peel, $5 \mathrm{~g}$ thinly cut were blended with 2 portions of ethyl acetate $(25 \mathrm{ml})$ and sodium sulphate $(4 \mathrm{~g})$. The homogenate was centrifuged in a Sorvall centrifuge at $4000 \mathrm{rpm}$ (2430 G), ambient temperature during 15 min. After shaking and centrifugation, the organic phases collected from the 2 extractions were pooled and dried in a rotary evaporator at $45^{\circ} \mathrm{C}$. The residue of kaki samples were dissolved in $20 \mathrm{ml}$ of a solution of cyclohexane/ethyl acetate (9.5:0.5), 2.0 $\mu l$ of this solution was injected in the GC/ECD system under the following conditions: split injection mode with a ratio of 30 ; injector temperature, $240^{\circ} \mathrm{C}$; detector temperature, $300^{\circ} \mathrm{C}$; carrier gas, helium and make-up nitrogen. The GC was operated in constant flow mode at $1 \mathrm{ml} / \mathrm{min}$ and temperature program applied was: hold $1.0 \mathrm{~min}$ at $70^{\circ} \mathrm{C}$, increase to $240^{\circ} \mathrm{C}$ at $20^{\circ} \mathrm{C} / \mathrm{min}$, and finally increase to $265^{\circ} \mathrm{C}$ at $20^{\circ} \mathrm{C} / \mathrm{min}$ hold 5 min. A Chrompack capillary column CP-Sil 8 CB Low Bleed/MS, 30 m x 0.25 mm ID 
and a 2-meter length fused silica tubing uncoated $0.25 \mathrm{~mm}$ ID purchased from Varian Iberia (Madrid, Spain) were used. Compounds were identified according to their retention times and quantified with the external standard calibration curve. Mixed standard solutions of captan and folpet were prepared from the stock solutions dissolved in cyclohexane/ethyl acetate (9.5/0.5) at concentrations ranging from 0.01 to $2 \mu \mathrm{g} / \mathrm{ml}$.

Trichlorfon GC-ECD determination. Twenty-five grams of whole raw, flesh and cooked kaki, homogenized in a blender were mixed in a rotary stirrer ( $5 \mathrm{~min}$ ) with $50 \mathrm{ml}$ ethyl acetate and $20 \mathrm{~g}$ of sodium sulphate. For the analysis of peel, $2.5 \mathrm{~g}$ thinly cut were blended with $25 \mathrm{ml}$ ethyl acetate and $2 \mathrm{~g}$ of sodium sulphate. The homogenate was centrifuged in a Sorvall centrifuge at $4000 \mathrm{rpm}(2430 \mathrm{G}), 4^{\circ} \mathrm{C}$, during $15 \mathrm{~min}$. After shaking and centrifugation, the organic phase was adjusted to 50 or $25 \mathrm{ml}$ with ethyl acetate, respectively, $2.0 \mu \mathrm{l}$ of this extract was injected in the GC-ECD system. Overall extraction procedure was performed under cold conditions. Chromatographic conditions were as follows: on column injection mode; injector temperature, $100^{\circ} \mathrm{C}$, hold $0.10 \mathrm{~min}$, increase to $200^{\circ} \mathrm{C}$ at $150^{\circ} \mathrm{C} / \mathrm{min}$, hold $5.0 \mathrm{~min}$; detector temperature, $250^{\circ} \mathrm{C}$; carrier gas, helium and make-up nitrogen. The GC operated in constant flow mode at $2.5 \mathrm{ml} / \mathrm{min}$ and temperature program was: hold $2.0 \mathrm{~min}$ at $60^{\circ} \mathrm{C}$, increase to $160^{\circ} \mathrm{C}$ at $15^{\circ} \mathrm{C} / \mathrm{min}$, and hold 8.0 min. A Chrompack capillary column CP-Sil $24 \mathrm{CB}, 15 \mathrm{~m}$ x $0.32 \mathrm{~mm}$ ID purchased from Varian Iberia (Madrid, Spain) was used. Compounds were quantified with the external standard calibration curve. Mixed standard solutions of trichlorfon and dichlorvos were prepared from the stock solutions dissolved in ethyl acetate at concentrations ranging from 0.025 to $0.50 \mu \mathrm{g} / \mathrm{ml}$. 


\section{Results and discussion \\ Raw kaki residue levels}

The determination of captan and folpet and trichlorfon residues in the samples was conducted by applying the GC-MS method or the LC-MS/MS methods described, respectively. Both methods were validated according to GLP protocol of the laboratory and performed considering accuracy (recovery experiments), precision, selectivity and limit of quantification (LOQ) according to European requirements and guidelines (European Communities 1996, European Commission 2000a). Accuracy and precision were studied using fortified samples at two concentration levels $(0.05$ and $0.5 \mathrm{mg} / \mathrm{kg}$, $\mathrm{n}=5$ ) which were run obtaining satisfactory recoveries between 93 to $107 \%$ for captan and folpet and between 97 to $101 \%$ for trichlorfon with relative standard deviations (RSDs) lower than 7\% (see "Table II"). The limit of quantification, defined as the lowest concentration tested, at which an acceptable mean recovery is obtained (70 to $110 \%$ ) with satisfactory precision (relative standard deviation lower than 20\%) (European Communities, 1996), were estimated to be $0.05 \mathrm{mg} / \mathrm{kg}$ for the three compounds. No interfering peaks appeared at the retention times of the compounds, thus demonstrating their selectivity.

“[Insert Table II about here]"

Residue levels of captan and folpet and trichlorfon were determined in the peel and pulp of raw kaki from 8 plots (4 plots in two consecutive years) at different times, to study the dissipation of the residue levels in the whole fruit with time and propose maximum residue limits in the established PHI (7 days for captan and 10 days for trichlorfon). The 
peel/flesh distribution data is required for fruits with inedible skin (European Commission 2000b).

Although the European residue definition for captan is the sum of captan and folpet, folpet could be detected not even at trace amounts. This was also observed in a study with captan applied to cauliflowers (Fernández-Cruz et al. 2005). Residue levels of captan and trichlorfon found in kaki fruits are reported in "Table III". No interfering peaks were observed in control plots and in samples harvested before treatment.

It could be observed that residue levels of captan in kaki remained in the same order during the study period with a mean (RSD) of $0.63 \mathrm{mg} / \mathrm{kg}(38 \%), 0.88 \mathrm{mg} / \mathrm{kg}(83 \%)$ and $0.78 \mathrm{mg} / \mathrm{kg}(78 \%), 3$ hours, 3 days and 7 days after treatment, respectively ("see Table III"). The same trend was observed with results found in 3 plots by GC-ECD analysis. No dissipation of residues was observed 7 days after treatment with a mean (RSD) of $0.28 \mathrm{mg} / \mathrm{kg}(47 \%)$ and $0.20 \mathrm{mg} / \mathrm{kg}(25 \%), 3$ hours and 7 days after treatment, respectively (“see Table VI").

“[Insert Table III about here]"

To study the dissipation of the residue, mean values at each time ("see Table III") of the four plots designed for dissipation studies (kaki plots $1,4,5,7$ ) have been analysed by a non-linear least squares regression with the program STATGRAPHICS Plus 4.1 Version and fitting data to a first-order kinetic with the following equation:

$$
\mathrm{C}_{\mathrm{t}}=\mathrm{C}_{0} \mathrm{e}^{-\mathrm{kt}}
$$

Where $\mathrm{C}_{\mathrm{t}}$ is the estimated concentration at a time $\mathrm{t}$, 
$\mathrm{C}_{0}$ is the estimated maximum initial concentration at time 0 ,

$\mathrm{K}$ is the slope of dissipation.

Half-life of the residue was calculated with the equation:

$$
\mathrm{t}_{1 / 2}=\ln 2 / \mathrm{k}
$$

Dissipation curves of captan and trichlorfon in kaki are reported in "Figure 1". The halflife of dissipation of captan in kaki could not be calculated from these data, as a diminution in residue levels was not observed 7 days after treatment. Dissipation of trichlorfon in kaki fitted adequately to a first-order kinetic $\left(\mathrm{C}=4.0088 * \mathrm{e}^{-0.0981 \mathrm{t}}\right)$ with a coefficient of correlation $R^{2}$ of 0.86 . Dissipation of the residue was slow with a $t_{1 / 2}$ of 7.1 days. A study of residues of trichlorfon in olives after olive tree treatments with trichlorfon (Dipterex 40 soluble concentrate (SL), $200 \mathrm{~g} / \mathrm{ha}$ ) shows a higher elimination of trichlorfon in 10 days from 0.981 to $0.103 \mathrm{mg} / \mathrm{kg}$ (Cavanna and Molinari 1998). Another study from four different sites obtained each in greenhouse or field-treated bananas with trichlorfon $80 \%$ SP, 320 g a.s/Hl (Otazo et al. 1998) indicate elimination half-lives of 5.3 and 6.7 days for field-banana and greenhouse-banana, respectively. "[Insert Figure 1 about here]"

Results obtained at the PHI permitted the proposal of an MRL following the European guideline of calculation of MRL (European Commission 1997) using method I which assumes a normal distribution for the measured residues and method II that uses a distribution-free parameter at the $75 \%$ quantile to calculate maximum residue value (Rmax) and proposed maximum residue level $\mathrm{R}($ ber), respectively. 
Results obtained for captan 7 days after treatment were $0.76,0.40,0.34,0.31,1.60$, $1.84,0.71$ and $0.29 \mathrm{mg} / \mathrm{kg}$. From these results $\mathrm{Rmax}$ and $\mathrm{R}($ ber) were respectively 2.76 and $2.72 \mathrm{mg} / \mathrm{kg}$. On the basis of these results and according to the guideline mentioned these results should be round up to the following maximum residue level classes. A MRL of $3 \mathrm{mg} / \mathrm{kg}$ for captan is proposed in kaki. The European maximum residue limit established for captan in kaki is the limit of detection of the technique that is $0.1 \mathrm{mg} / \mathrm{kg}$. Analytical methods developed in our laboratories allowed lower limits of detection. Maximum residue level means "the upper legal level of a concentration for a pesticide residue in or on food or feed set in accordance with the Regulation 396/2005/EC (European Union 2005), based on good agricultural practice and the lowest consumer exposure necessary to protect vulnerable consumers". It is clear that, before setting or modifying a MRL, an assessment of the risks of exceeding the acceptable daily intake (short-term exposure) or acute reference dose (acute exposure) should be provided as well as, if necessary, the measures to take to reduce the LMR value (higher PHI, lower application doses, etc.).

Results obtained for trichlorfon at the PHI were 1.99, 0.32, 1.71, 1.15, 2.44, 1.85, 0.98 and $1.79 \mathrm{mg} / \mathrm{kg}$. Rmax and $\mathrm{R}($ ber) were respectively 3.91 and $3.67 \mathrm{mg} / \mathrm{kg}$. MRL for trichlorfon in kaki should be fixed in $5 \mathrm{mg} / \mathrm{kg}$ that is the recommended following maximum residue level classes. The current European maximum residue limit established in the group of miscellaneous fruits is $0.5 \mathrm{mg} / \mathrm{kg}$. As for captan, a consumer risk assessment of this residue level should be conducted before setting the new MRL. 


\section{Residue variability among individual fruits}

Recently, the possible risk associated with the presence of higher residues on individual food items than in the composite samples, from which MRLs are based, has been considered for an acute exposure (WHO 1997). Originally, in the absence of data, default values for variability factors ( $v$ ) (ratio of highest level of residue in the individual size samples to the corresponding residue levels in the composite samples) have been set in 5 for large crops (commodities weights $>250 \mathrm{~g}$ ) and in 10 (latter in 7) for medium crops (commodities weights between 25 and $250 \mathrm{~g}$ ). Under current European Union (EU) procedures, variability factors are considered for conducting consumer acute exposure assessments before granting authorization of uses of plant protection products and setting of MRLs (EFSA 2005). These default values have been refined consecutively with the new data available. Hamilton et al. (2004) proposed to adopt a default variability factor of 3 for all commodities with unit weight exceeding 25 g. The Scientific Panel on Plant Health, Plant Protection Products and their Residues of the European Food Safety Authority (EFSA-PPR) (EFSA 2005) has studied this proposal. Their conclusions have been that the variability factors for supervised trials will exceed the proposed default value of 3 in $34 \%$ of cases, whereas the previous default value of 7 for medium-sized food items will be exceeded in $0.2 \%$ of cases. This should be considered when choosing an appropriate default value for use in dietary exposure assessments. To assist in this the EFSA-PPR Panel provides tables presenting a range of statistics. However they consider that the available data are not enough and their recommendations are that it would be very desirable to obtain and analyse additional supervised trials to more fully represent the different regions of the EU (EFSA 2005). 
At the beginning of our study the samples units that should be analysed were not indicated nor proposed. Currently, Hamilton et al. (2004) recommend studies with 100 items whereas the PPR Panel consider studies with at least 50 items. In our design, we choose to collect in each plot the same number of units that forms a composite sample as MRLs are fixed in base to these samples. In our case (18 units) the $97.5^{\text {th }}$ percentile value coincide to the highest level of residue in the individual size samples.

The variability of residue levels of captan and trichlorfon between individual fruits (6 individual fruits from 3 plots) 3 hours and 7 or 10 days after treatment were analysed as well as composite samples of another 6 fruits collected from the same plots. Residue levels were analysed with the GC-ECD methods described. The methods have been single-laboratory validated for the determination of captan and folpet and trichlorfon and its metabolite dichlorvos in whole kaki fruits. No interfering peaks appeared at the retention times of the compounds. Quantification was carried out using calibration curves of 5-6 calibrations points of mixed standard solutions ranging from 0.01 to 2 $\mu \mathrm{g} / \mathrm{ml}$ for captan and folpet and from 0.025 to $0.50 \mu \mathrm{g} / \mathrm{ml}$ for trichlorfon and dichlorvos. The linearity in the two methods was very good $\left(\mathrm{R}^{2}>0.99\right)$. Satisfactory recoveries of 
five replicates at 0.04 and $0.4 \mathrm{mg} / \mathrm{kg}$ ranging between 89 to $102 \%$ were gotten with RSD lower than $15 \%$ for captan and folpet (see "Table IV"). Recoveries of three replicates at $0.05,0.1$ and $1 \mathrm{mg} / \mathrm{kg}$ ranging between $92-111 \%$ for dichlorvos and 80 $113 \%$ for trichlorfon were obtained with RSD lower than $9 \%$ (see "Table IV"). Quantification limits (LOQ) were $0.04 \mathrm{mg} / \mathrm{kg}$ for captan and folpet and $0.05 \mathrm{mg} / \mathrm{kg}$ for trichlorfon and dichlorvos.

"[Insert Table IV about here]"

“[Insert Table V about here]"

Dichlorvos and folpet could not be detected in any of the samples. Results of captan and trichlorfon in individual size versus composite samples are reported in "Table V". The residues of captan in each fruit ranged from 0.14 to $0.89 \mathrm{mg} / \mathrm{kg}, 3$ hours post-treatment and from 0.08 to $0.52 \mathrm{mg} / \mathrm{kg}, 7$ days post-treatment. The residue concentrations in composite samples ranged from 0.13 to $0.37 \mathrm{mg} / \mathrm{kg}$ with an average of $0.28 \mathrm{mg} / \mathrm{kg}$ and RSD $47 \%$ and 0.15 to $0.25 \mathrm{mg} / \mathrm{kg}$ with an average of $0.20 \mathrm{mg} / \mathrm{kg}$ and $\mathrm{RSD} 25 \%, 3$ hours and 7 days post-treatment, respectively ("see Table V"). With these results variability factors $(v)$ were estimated to be 3.2 and $2.6,3$ hours and 7 days postapplication, respectively. A comparison of the concentration levels of captan, 7 days after treatment, in the 18 individual fruits with the average concentrations in the composite samples showed that nine individual fruits $(50 \%)$ contained higher residues than the average value $(0.20 \mathrm{mg} / \mathrm{kg})$. Four of these fruits duplicated the average value and one fruit almost tripled the value. 
In our study the default variability factor of 3 is adequate for the risk assessment of captan and trichlorfon in kaki fruits.

\section{Effect of household processing on residue levels}

The major factors influencing the stability of the residue in typical processes are temperature, $\mathrm{pH}$, water content and chemical nature of the residues. The effect of household processing on residue levels of captan and trichlorfon in kaki fruits has been studied. Kaki fruits are eaten raw normally without its peel. The fruit is also used in the elaboration of marmalades and in pastry. The distribution of residue levels in kaki flesh and peel and the effect of temperature on levels of these compounds have been assayed. The presence of dichlorvos and folpet has also been studied.

Residue levels have been determined by the described GC-ECD analytical methods. Recovery assays of captan and folpet at 0.04 and $0.4 \mathrm{mg} / \mathrm{kg}$ in kaki matrices (peel and whole boiled kaki, $\mathrm{n}=3$ ) ranged between 79 and $106 \%$ with $\mathrm{RSD}<15 \%$ (see "Table IV"). Recoveries of trichlorfon and dichlorvos at 0.05 and $0.5 \mathrm{mg} / \mathrm{kg}$ in kaki peel and in 
whole boiled kaki (n=3) ranged between 65 and $111 \%$ for dichlorvos and 76 and $103 \%$ for trichlorfon with RSD<12\% (see "Table IV").

Folpet could not be detected in any of the samples analysed. Dichlorvos was detected in cooked samples. Residue levels of captan and trichlorfon obtained after household processing are reported in "Table VI".

“[Insert Table VI about here]"

Captan and trichlorfon are classified as non-systemic. Results in peel and flesh indicated that captan residues practically remained in peel. Processing factors are used to characterise the transfer of residue from fresh crop into processed fraction .The average processing factor is calculated dividing concentration in processed commodity by concentration in raw agricultural commodity. For captan this factor is 1 in peel and 0 in flesh.

On the contrary trichlorfon could penetrate into the flesh. The percentage weight of peel and flesh in kaki fruits is 11 and $89 \%$, respectively. The distribution of trichlorfon between flesh versus peel 3-hours and 10-days after treatment was 20 and $70 \%$, respectively, showing a fast penetration of the residue. The processing factor for trichlorfon in peel and in flesh is 0.2 and 0.7 , respectively. This result is in contradiction with other non-systemic pesticides, fenitrothion in kaki (Fernández-Cruz et al. 2004), chlorpropham in potatoes (Lentza-Rizos and Balokas 2001), cypermethrin, diazinon and parathion in carrots (Burchat et al. 1998), where the amount of residue removed by peeling was higher than $90 \%$. Trichlorfon is highly soluble in water $(120 \mathrm{~g} / \mathrm{l})$, whereas 
the water solubility of cypermethrin, captan, parathion, fenitrothion, diazinon and chlorpropham range from 0.01 to $89 \mathrm{mg} / \mathrm{l}$. This fact could explain the ease of trichlorfon to penetrate across the kaki peel.

Temperature did result in an evident decrease of residue levels of captan after cooking kaki fruits without water during 20 minutes ("see Table VI"). Trace amounts of captan could only be detected. The transfer factor is 0. Previous studies (Alary et al. 1995, Fernández-Cruz et al. 2005) reported a complete degradation of captan by temperature.

Cooking kaki fruits, bubbling 20 min, results in a mean loose of weight of $77 \%$. To compare the residue levels of trichlorfon in raw and cooked material, the residue levels should be corrected for the concentration (see "Table VI"). It is described that trichlorfon is thermo-labile and decomposes to dichlorvos at high temperatures. As it could be expected dichlorvos could be detected in cooked samples. The decrease of residue levels of trichlorfon at PHI was of $27 \%$, with an average processing factor of 0.8 .

In conclusion, field trials permitted the proposal of maximum residue levels in kaki of 3 and $5 \mathrm{mg} / \mathrm{kg}$ for captan and trichlorfon, respectively. A variability factor between units could be set in 3 for the acute risk assessment. No dissipation of captan residue levels was observed 7 days after treatment. Dissipation of trichlorfon was slow with a $t_{1 / 2}$ of 7.1 days. Levels of captan decreased more than $90 \%$ after peeling whereas trichlorfon penetrated into the flesh in a proportion of $70 \%$ of the residue, 10 days after treatment. The processing factors in peel for captan and trichlorfon were 1 and 0.2 , 
respectively and, 0 and 0.7 in pulp, respectively. Cooking kaki fruits resulted in a decrease of $27 \%$ of the residue levels of trichlorfon and a complete degradation of captan indicating that processing factors should be fixed in 0.8 and 0 , respectively.

\section{References}

Alary J, Bescos D, Monge MC, Debrauwer L, Bories GF. 1995. Laboratory simulation of captan residues degradation during apple processing. Food chemistry 54:205-211.

Angioni A, Garau VL, Aguilera del Real A, Melis M, Minelli EV, Tuberoso C, Cabras P. 2003. GC-ITMS determination and degradation of captan during wine making. Journal of Agricultural and Food Chemistry 51:6761-6766.

Barreda M, López FJ, Villarroya M, Beltran J, García-Baudín JM, Hernández F. Residue determination of captan and folpet in vegetable samples by NCI GC-MS. Journal of AOAC International (submitted)

Brito NM, Navickiene S, Polese L, Jardim EFG, Abakerli RB, Ribeiro ML. 2002. Determination of pesticide residues in coconut water by liquid-liquid extraction and gas chromatography with electron-capture plus thermionic detection and solid-phase extraction and high-performance liquid chromatography with ultraviolet detection. Journal of Chromatography A 957:201-209. 
Burchat CS, Ripley BD, Leishman PD, Ritcey GM, Kakuda Y, Stephenson GR. 1998. The distribution of nine pesticides between the juice and pulp of carrots and tomatoes after home processing. Food Additives and Contaminants 15:61-71.

Cavanna S, Molinari GP. 1998. Residues of fenthion and trichlorofon in olives and olive oil after olive tree treatments. Food Additives and Contaminants. 15:518-527.

Conrad R, Dedek W, Engewald W. 1987. Determination of trichlorfon in biological media and technical products following derivatization with acetic-anhydride by gas chromatography. Fresenius' Zeitschrift fur Analytische Chemie 326:241-246.

EFSA (European Food Safety Authority). 2005. Opinion of the Scientific Panel on Plant health, Plant protection products and their Residues on a request from Commission related to the appropriate variability factor(s) to be used for acute dietary exposure assessment of pesticide residues in fruit and vegetables. The EFSA Journal 177:1-61. http://www.efsa.eu.int/science/ppr/ppr_opinions/catindex_en.html.

European Commission. 1997. Appendix I: Calculation of maximum residue levels and safety intervals. In Doc. 7039/VI/95. Directorate General for Agriculture. European Commission. p. 13.

European Commission. 2000a. Guidance document on residue analytical methods. In Doc. SANCO/825/00 rev.6; Directorate General Health and Consumer Protection. European Commission. p 16. 
European Commission. 2000b. Appendix B: General recommendations for the design, preparation and realization of residue trials. In: Doc. 7029/VI/95 rev.6. Directorate EFood safety: plant health, animal health and welfare, international questions, E1-Plant health. European Commission. p 72.

European Communities. 1996. Commission Directive 96/46/EC of 16 July 1996 amending Council Directive 91/414/EEC concerning the placing of plant protection products on the market. Official Journal of the European Communities L 214:18-24.

European Union. 2005. Regulation (EC) № 396/2005 of the European Parliament and of the Council of 23 February 2005 on maximum residue levels of pesticides in or on food and feed of plant and animal origin and amending Council Directive 91/414/EEC. Official Journal of the European Union L 70:1-16.

Fernández-Cruz ML, Villarroya M, Llanos S, Alonso-Prados JL, García-Baudín JM. 2004. Field incurred fenitrothion residues in kakis: comparison of individual fruits, composite samples, peeled and cooked fruits. Journal of Agricultural and Food Chemistry 52:860-863.

Fernández-Cruz ML, Barreda M, Villarroya M, Peruga A, Llanos S, García-Baudín JM. . Captan and fenitrothion dissipation in field-treated cauliflowers, effect of household processing. Pest Management Science (submitted). 
Hamilton D, Ambrus A, Dieterle R, Felsot A, Harris C, Petersen B, Racke K, Wong SS, Gonzalez R, Tanaka K, Earl M, Roberts G, Bhula R. 2004. Pesticide residues in food acute dietary exposure. Pest Management Science 60:311-339.

Lentza-Rizos Ch, Balokas A. 2001. Residue levels of chlorpropham in individual tubers and composite samples of postharvest-treated potatoes. Journal of Agricultural and Food Chemistry 49:710-714.

Mattern GC, Singer GM, Louis J, Rosen JD. 1990. Determination of several pesticides with a chemical ionization ion trap detector. Journal of Agricultural and Food Chemistry 38:402-407.

Mattern GC, Liu CH, Louis JB, Rosen JD. 1991. GC/MS ad LC/MS determination of 20 pesticides for which dietary oncogenic risk has been estimated. Journal of Agricultural and Food Chemistry 39:700-704.

\begin{abstract}
Niessner G, Buchberger W, Eckerstorfer R. 1999. Multiresidue screening methods for the determination of pesticides in plant materials. Journal of Chromatography A 846:
\end{abstract} 341-348.

Otazo C, Ortega MP, González A, Gamón M. 1998. Degradation studies of commonly used pesticides in banana plantations in the Canary Islands. Acta Horticulturae 490:395405. 
Spieszalski W, Niemczyk HD. 1991. Improved gas chromatographic method for analysis of trichlorfon insecticide in soil and turfgrass thatch. Journal of Environmental Science and Health Part B 26: 575-588.

WHO (World Health Organization). 1997. Food Consumption and exposure assessment of Chemicals. Report of the FAO/WHO Consultation. Geneva: World Health Organization. P 69. 
Table I. Meteorological data collected in agro meteorological stations during the treatment and sampling periods

\begin{tabular}{|c|c|c|c|c|c|c|c|c|}
\hline Plot & $\mathbf{1}$ & 2 & 3 & 4 & 5 & 6 & 7 & 8 \\
\hline \multicolumn{9}{|c|}{ Captan } \\
\hline Period of & $15 / 10 / 02$ & $14 / 10 / 02$ & $07 / 10 / 02$ & $08 / 10 / 02$ & $06 / 10 / 03$ & $02 / 10 / 03$ & $20 / 10 / 03$ & $04 / 11 / 03$ \\
\hline study & $22 / 10 / 02$ & $21 / 10 / 02$ & $14 / 10 / 02$ & $15 / 10 / 02$ & $13 / 10 / 03$ & 09/10/03 & $27 / 10 / 03$ & $11 / 11 / 03$ \\
\hline \multirow{2}{*}{$\begin{array}{l}\text { Medium } \\
\operatorname{Temp}\left({ }^{\circ} \mathrm{C}\right)\end{array}$} & & & & & & & & \\
\hline & 17.4 & 18.1 & 18.9 & 18.9 & 18.7 & 19.3 & 13.6 & 13.7 \\
\hline Daily/(Total) & 0.0 & $0.0-0.4$ & $0.0-3.0$ & $0.0-2.2$ & $0.0-0.3$ & $0.0-15.4$ & $0.0-13.8$ & $0.0-7.1$ \\
\hline rainfall(mm) & $(0.0)$ & $(0.4)$ & (5.4) & $(4.2)$ & $(1.0)$ & (18.0) & (27.0) & (7.3) \\
\hline
\end{tabular}

Trichlorfon

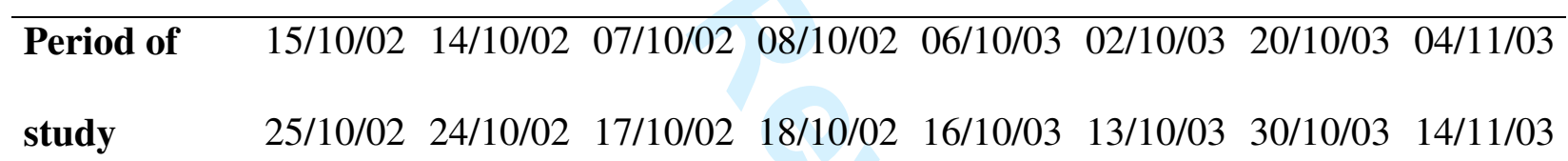

\begin{tabular}{lcccccccc}
\hline Medium & 17.2 & 18.3 & 19.1 & 18.6 & 18.2 & 19.5 & 14.2 & 13.5 \\
Temp $\left({ }^{\circ} \mathbf{C}\right)$ & & & & & & & & \\
\hline Daily/(Total) & 0.0 & $0.0-0.4$ & $0.0-3.0$ & $0.0-2.2$ & $0.0-19.8$ & $0.0-15.4$ & $0.0-13.8$ & $0.0-7.1$ \\
rainfall(mm) & $(0.0)$ & $(0.4)$ & $(5.8)$ & $(6.4)$ & $(31.3)$ & $(18.4)$ & $(27.2)$ & $(7.3)$
\end{tabular}


Table II. Data of the analytical captan/folpet GC/MS method and trichlorfon LC-MS/MS method

\begin{tabular}{cccc}
\hline $\begin{array}{c}\text { Compound } \\
\text { Fortification } \\
(\mathbf{m g} / \mathbf{k g})\end{array}$ & $\begin{array}{c}\text { Flesh Recovery (\%) } \\
(\text { RSD \% })^{a}\end{array}$ & $\begin{array}{c}\text { Peel Recovery (\%) } \\
(\text { RSD \% })^{a}\end{array}$ \\
\hline Captan & 0.05 & $98(3)$ & $100(4)$ \\
Folpet & 0.50 & $94(1)$ & $97(1)$ \\
& 0.05 & $107(4)$ & $97(2)$ \\
\hline Trichlorfon & 0.50 & $105(2)$ & $93(7)$ \\
& 0.05 & LC-MS/MS & $98(4)$ \\
& 0.50 & $98(7)$ & $101(6)$ \\
\hline${ }^{a}$ Mean of 5 replicates & $97(3)$ &
\end{tabular}


Table III. Kaki fruit residue levels (mg/kg) of captan determined by GC/MS and trichlorfon determined by LC-MS/MS

\begin{tabular}{|c|c|c|c|c|c|c|c|c|c|c|}
\hline Time & Plot 1 & Plot 2 & Plot 3 & Plot 4 & Plot 5 & Plot 6 & Plot 7 & Plot 8 & mean & RSD (\%) \\
\hline \multicolumn{11}{|c|}{ Captan } \\
\hline $3 \mathrm{~h}$ & 0.83 & 0.49 & 0.63 & 0.45 & 0.97 & 0.90 & 0.38 & 0.39 & 0.63 & 38 \\
\hline $3 d$ & 0.95 & & & 0.31 & 1.89 & & 0.37 & & 0.88 & 83 \\
\hline $7 \mathrm{~d}$ & 0.76 & 0.40 & 0.34 & 0.31 & 1.60 & 1.84 & 0.71 & 0.29 & 0.78 & 78 \\
\hline \multicolumn{11}{|c|}{ Trichlorfon } \\
\hline $3 \mathrm{~h}$ & 3.55 & 2.33 & 5.11 & 3.05 & 5.84 & 7.29 & 2.16 & 4.51 & 4.23 & 42 \\
\hline $2 d$ & 3.62 & & & 2.09 & 7.67 & & 1.84 & & 3.81 & 71 \\
\hline $5 \mathrm{~d}$ & 1.95 & & & 1.60 & 5.19 & & 1.52 & & 2.57 & 69 \\
\hline $7 d$ & 2.21 & & & 1.04 & 1.52 & & 1.40 & & 1.54 & 32 \\
\hline $10 \mathrm{~d}$ & 1.99 & 0.32 & 1.71 & 1.15 & 2.44 & 1.85 & 0.98 & 1.79 & 1.53 & 44 \\
\hline
\end{tabular}


Table IV. Analytical data of captan/folpet and trichlorfon GC/ECD methods

\begin{tabular}{|c|c|c|c|c|}
\hline \multirow{2}{*}{ Compound } & \multirow{2}{*}{$\begin{array}{l}\text { (mg/kg) } \\
\text { (mgication }\end{array}$} & \multicolumn{3}{|c|}{ Recovery (\%) (RSD \%) } \\
\hline & & Fruit & Peel & Boiled \\
\hline \multirow{2}{*}{ Captan } & 0.04 & $97(15)^{a}$ & $79(15)^{b}$ & $86(13)^{b}$ \\
\hline & 0.40 & $102(11)^{a}$ & $106(10)^{b}$ & $106(7)^{b}$ \\
\hline \multirow{2}{*}{ Folpet } & 0.04 & $89(7)^{a}$ & $102(12)^{b}$ & $84(12)^{b}$ \\
\hline & 0.40 & $101(6)^{a}$ & $102(5)^{b}$ & $106(5)^{b}$ \\
\hline \multirow[t]{4}{*}{ Trichlorfon } & 0.05 & $80(8)^{b}$ & $76(3)^{b}$ & $76(3)^{b}$ \\
\hline & 0.1 & $113(2)^{b}$ & & \\
\hline & 0.5 & & $100(7)^{b}$ & $103(3)^{b}$ \\
\hline & 1 & $97(2)^{b}$ & & \\
\hline \multirow[t]{4}{*}{ Dichlorvos } & 0.05 & $102(3)^{b}$ & $70(4)^{b}$ & $111(3)^{b}$ \\
\hline & 0.1 & $111(9)^{b}$ & & \\
\hline & 0.5 & & $65(12)^{b}$ & $86(4)^{b}$ \\
\hline & 1 & $92(6)^{b}$ & & \\
\hline
\end{tabular}


Table V. Residues (mg/kg) of captan and trichlorfon in individual size and composite samples of kaki fruits determined by GC-ECD.

\begin{tabular}{|c|c|c|c|c|}
\hline & $\begin{array}{l}\text { Captan } \\
(\mathrm{mg} / \mathrm{kg})\end{array}$ & $\begin{array}{l}\text { Trichlorfon } \\
\text { (mg/kg) }\end{array}$ & $\begin{array}{l}\text { Captan } \\
(\mathrm{mg} / \mathrm{kg})\end{array}$ & $\begin{array}{c}\text { Trichlorfon } \\
(\mathrm{mg} / \mathrm{kg})\end{array}$ \\
\hline 8 & 3 hours & 3 hours & 7 days & 10 days \\
\hline \multicolumn{5}{|c|}{ Individual kaki fruits $(n=18)$} \\
\hline mean $(\operatorname{RSD}(\%))$ & $0.47(37)$ & $2.71(38)$ & $0.24(53)$ & $0.74(60)$ \\
\hline $\min / \max$ values & $0.14 / 0.89$ & $0.79 / 5.01$ & $0.08 / 0.52$ & $0.20 / 2.06$ \\
\hline \multicolumn{5}{|c|}{ Composite samples $(n=3)$} \\
\hline mean $(\mathrm{RSD}(\%))$ & $0.28(47)$ & $3.02(11)$ & $0.20(25)$ & $0.85(26)$ \\
\hline $\min /$ max values & $0.13 / 0.37$ & $2.72 / 3.38$ & $0.15 / 0.25$ & $0.71 / 1.11$ \\
\hline Variability factor & 3.2 & 1.6 & 2.6 & 2.4 \\
\hline
\end{tabular}


Table VI. Mean values for captan, triclorfon and dichlorvos residues $(\mathrm{mg} / \mathrm{kg}$ ) and RSD (\%) for composite and processed samples of kaki fruits from three plots (1, 3 and 4 for kaki) determined by GC-ECD

\begin{tabular}{ccccc}
\hline Time $^{a}$ & Whole Kaki & Peel & Flesh & Boiled \\
\hline Captan & & & & \\
$3 \mathrm{~h}$ & $0.28(47)$ & $3.80(30)$ & $<0.04$ & $<0.04$ \\
$7 \mathrm{~d}$ & $0.20(25)$ & $2.70(29)$ & $<0.04$ & $<0.04$
\end{tabular}

Trichlorfon

$\begin{array}{ccccc}3 \mathrm{~h} & 3.02(11) & 16.25(45) & 0.50(64) & 2.50(17)[1.92]^{b} \\ 10 \mathrm{~d} & 0.85(26) & 1.76(10) & 0.50(18) & 0.80(24)[0.62]^{b}\end{array}$

Dichlorvos

\begin{tabular}{|c|c|c|c|c|}
\hline $3 \mathrm{~h}$ & nd & nd & nd & $0.43(10)[0.33]^{b}$ \\
\hline $0 \mathrm{~d}$ & nd & nd & nd & $0.44(23)[0.34]^{b}$ \\
\hline
\end{tabular}

${ }^{a}$ Time after application; [] $]^{b}$ residue level corrected for the concentration; nd: non detected 


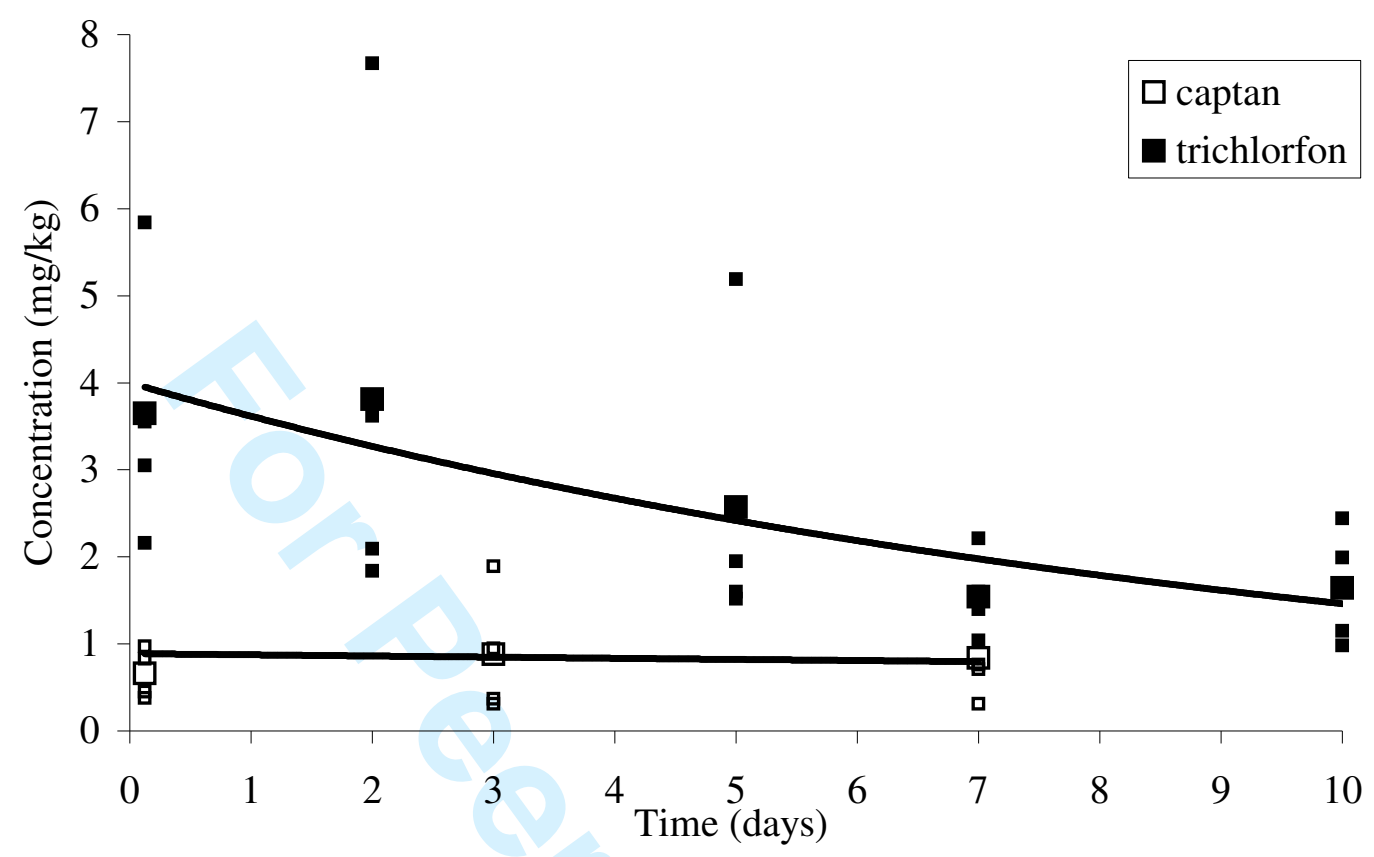

Figure 1. Dissipation curves of captan and trichlorfon in kaki fruits 